\title{
The Politics of Environmental History
}

\author{
H. Ritvo, The Dawn of Green: Manchester, Thirlmere and Modern
}

Environmentalism. Chicago, University of Chicago Press, 2009, 248 pages, \$26 hardback

T.C. Smout, Exploring Environmental History. Edinburgh, Edinburgh University Press, 2009, 256 pages, $£ 60$ hardback.

E. Burke and K. Pomeranz, The Environment and World History. Berkely LA, University of California Press, 2009, 384 pages, £41.95 hardback.

A. Hornborg, J. McNeill, and J. Martinez-Alier, Rethinking Environmental History. Lanham MD, Altamira Press, 2007, 420 pages, $£ 59.95$ hardback.

As the title suggests, in reviewing these recent books on environmental history I wish to reflect up the question of how historians should approach analysis of the 'environment' as history? To what extent does history even need yet another subdisciplinary identity? If we do need 'environmental history', what shape should that environmental history take? In their 2007 article on 'The Problem of the Problem of Environmental History' in Environmental History Paul Warde and Sverker Sörlin have argued that environmental history needs to take its connections with other historical disciplines much more seriously. In particular, they claim that environmental historians need to embed social and political theory within their practice if they are to contribute to the discipline as a whole. As the authors succinctly argue, 'How and with what purpose we write environmental history is crucial not just the fact that we write it'. Warde and Sörlin's argument should provide a serious call to arms among environmental historians to 'get serious' about theory, and there are already signs, particularly within the field's major journal, that theoretical and analytical problems are becoming more and more significant. This is an area in which historical geography should clearly have claim to influence the shape of debates within environmental history.

These efforts to move environmental history onto more rigorously theoretical terrain are welcome, but they obviously raise the moot point of which theory or theories are most useful. Such choices are, of course, always personal and ethical, and therefore political. The 'with what purpose' of Warde and Sörlin's essay raises exciting possibilities, but the authors' own desire to see a form of historical narrative emerge that will inform 'policy' and challenge the dominance of science based accounts of environmental transformation seems rather modest in ambition. It takes as given the political and economic conditions within which environmental history (and politics) operate, and offers in return, at best, the prospect of occasional influence over the ethics of policy-making. But as the Warde and Sörlin recognise elsewhere, it is the very fact of the historical and political (ideological) character of invocations of 'science', 'nature' and the 'environment' that environmental historians, among many others, have come to understand. Surrendering this crucial critical move to the needs of policy making, whatever the temptations of 'impact agendas' and the like would be a retrograde step. Indeed, the idea that environmental history should seek to influence 
'policy' in a narrow sense, rather than to engage in politics, demonstrates the importance of the choice of theoretical foundation. From the point of view of Marxist environmental history, for instance, there can be no question that merely influencing policy constitutes a sufficient response to the kinds of social transformation that are necessary to produce a socially and environmentally just order. Similarly, as the dismal, if predictable, failure of COP15 demonstrates, the very capacity of governments dominated by the priorities of capital accumulation to respond in a just and effective manner to global environmental problems is questionable. The exciting efforts of Rescue!History (http://rescue-history-from-climate-change.org/), for example, to engage environmental history in critically understanding of the sources of climate change and the requirements of 'transition' may, in this context, mean more than any amount of policy influence.

The question informing the books under review in this essay is the extent to which they suggest such a creative, critical theoretical approach is being pursued. To what extent are new social-theoretical angles being developed that can contribute not just to 'policy' but to political movements more broadly conceived? To what extent are the ideological conceptions of 'nature', 'environment', 'conservation', or 'environmental crisis' being subjected to critical attention. Is, following Marx's conception of a 'critical history of technology', a 'critical history of the environment' emerging in the present moment? The overall indications are, I think positive, though with some important reservations.

T.C. Smout's collection of essays Exploring Environmental History is the most disappointing of these publication when viewed from this perspective. Although deeply and impressively detailed, the essays collected in this volume are precisely indicative of the risks that are run when the relationship to 'policy' becomes too predominant concern (Smout highlights the influence of his own involvement with both the Nature Conservancy Council and Scottish Natural Heritage), edging out critical attention to the troubled politics of conservation and environmental protection. Disappointingly, despite a nod in the direction of Sörlin and Warde's call for theoretical reflection, Smout largely eschews theory for a narrow empiricism, and the difficulties this causes are present throughout the collection.

For instance, Smout declares that the purpose of environmental history is 'to place man in the context of his environment, not as master with dominion over nature but as part of nature and subject to its laws, and further to show how his actions have impacted on nature' (p.2). This might be thought un-objectionable (although the explicit gendering of this relationship is worth noting), but this understanding of environmental history is both epistemologically and theoretically questionable. It is clear that this mental conception of nature's 'laws' is critical to the interpretations Smout produces throughout this collection, and like others he is keen to encourage 'engagement and collaboration with science', the advantages of which are not really argued epistemologically so much as asserted dogmatically (p.3). Logically the utility of such collaboration would stem from science's unique access to, and comprehension of, these 'laws' of nature to which humanity is subject. Palynology is invoked as an particular example of this, and the science is invoked an a number of essays which attempt the reconstruction of historic environments. Clearly there is capacity for interesting collaborative work in such areas, but there is surely also reason for caution. The weight of recent science studies suggests that the production of scientific 
knowledge is more problematic than this picture allows. The very nature of scientific representation has become an subject of study and critique although Smout fails to acknowledge this. From a policy viewpoint it is of course convenient (even essential) to be able to claim that we can recapture and reconstruct the historic environment. But one wonders exactly what the historian can do here that the palynologist cannot. Indeed, Smout's references to fossil pollen evidence often feel more like the consequence of the belief that it should be significant than to add anything substantive to the historical sources upon which he draws, and of which he undoubtedly has a commanding knowledge. The cursory references in the chapters on 'Bogs and people in Scotland' and 'Trees as historic landscapes', where it appears that little such scientific work has yet been done, seem indicative in this regard.

One does not have to employ, what Smout dismisses as, 'the preposterous language of post-modernism' in order to suggest that historical methodology has its own epistemic validity and that this collection would have benefited from a more rigorous reflection upon the politics of invoking 'science' and its claims to be able to represent 'nature' (p. 4.). Indeed, Smout's dismissal of 'post-modernism' is suggestive of a resistance to theoretical reflection that permeates, and ultimately impoverishes, this collection. Smout claims that his history attempts 'objectivity' in representing the past, but in reality these essays are deeply ideological in both their conceptions of 'nature' and the purposes which their historical narratives serve. They assume, for example, that the emergence of a twentieth century conservationism dominated by a scientific cadre of experts constituted a progressive historical movement. Ireland, for example, is written off as 'the most backward of all western European nations in respect to conservationism' (p.49.). In a chapter on 'The roots of green consciousness', Smout argues that the problem with community-based conservation efforts is that 'a community might prefer, for local reasons, to embark on a course of action damaging to a national or international interest'. Notions of 'national' interest here are represented as uncontested. Fortunately, we are informed:

'In practice, however, this risk is not great, since national and international rules and regulations (top-down in origin) now limit what a local community can do. It is not fashionable to say so, but it is probably just as well that the history of green consciousness worked in such a way that top down preceded bottom-up. Top-down set the rules of the game; bottom-up may be the best way to implement them' (p.51)

Much the same attitude, which far from being 'objective' clearly has political implications, informs Smout's account of Scottish improvers, who emerge as scientifically informed experts rescuing an 'environment heavily stressed by misuse' (p.151). Regardless of the truth claims here, these positions do not sit comfortably alongside the author's introductory attack on 'ideologues cherry-picking facts and examples from the past to support a particular point of view' (p.5.).

In short this volume, for all its undoubted empirical rigour tells a story for which it refuses to admit any responsibility. The rule of the expert is validated, against the unsustainable anarchy of democratic claims to resource use and the shaping of nature. The 'policy' implications are suggestive, and one suspects that this history speaks largely to conservation organisations in their role as guardians of scientific truth. Smout's history consistently prioritises the needs of a 'nature' which contains 
formations that are objectively better or worse, and in which a hierarchy of experts, private property and environmental history come together to preserve what is good from self-interested communities, constituted in practice from those with the least social power. Ultimately, for all its empirical rigour, Exploring Environmental History fails to advance environmental history in terms of theory or analysis.

None of this should suggest for one moment a rejection on the part of this reviewer of the importance of empirical approaches to environmental history. Harriet Ritvo's The Dawn of Green: Manchester, Thirlmere and Modern Environmentalism, is suggestive of the ways in which a rich empirical study can build into a significant analytical contribution to environmental history. This monograph's conceptual insights are developed from a detailed study of the nineteenth-century development of Thirlmere as a water resource for the city of Manchester. Ritvo provides a delicately nuanced historical narrative of the Romantic imagination of the Lakes, the industrial city's appropriation of Thirlmere and the ultimate roots and weakness of its defence by the Thirlmere Defence Association, and elegantly represents the nuances and ambiguities involved in this defence. Ritvo is at her best when analysing the languages and genres in which the defence of Thirlmere was articulate, and the range of literary artefacts and visual sources she employs in analysing the cultural construction and counterconstruction of Thirlmere as both Romantic landscape and urban natural resource is impressive, demonstrating the considerable contribution that literary scholarship can make in understanding the languages of environmental politics.

Although not explicitly theorised, one of the issues that comes across strongly in The Dawn of Green is the role of water in the political ecology of industrial capitalism. Ritvo demonstrates the crucial importance of water to the industrial development of Manchester and this book can be usefully read alongside William Cronon's classic Nature's Metropolis. What is also apparent are the ways in which Cottonopolis tended to undermine its own political ecology. The pollution of Manchester's major rivers, and the demands on the water supply made by the needs of industrial development, clearly threatened to expose contradictions in the relationship to nature. Water was crucial to the valorisation of capital. Not only were the city authorities reluctant to promote the spread of domestic water supplies as they might compete with industrial demand, but water also played a role in the production of property capital and the remaking of urban geography. One of the effects of earlier water provision schemes such as the Longendale Reservoir, which was completed in 1851, was that fire control became much more effective, enabling capitalists to realize value by building far taller buildings and warehouses (p.61). Manchester's capacity to reproduce its working class, was clearly tested by the environmental conditions that accompanied industrial pollution and urban poverty. Relative lack of water, and the problem of disposing of waste and sewage, presented the Manchester's elites with a serious legitimacy crisis. It was all too easy for critics to point to the poor health of the city's industrial workforce and the waste that filled streets as examples of the failures of industrial capitalism. Engels, as Ritvo notes, had good reason to dwell as effectively as he did on the filth and ordure that contrasted so starkly with the emerging civic and private splendour of the city (p.44).

While in the round The Dawn of Green is not a theoretically driven book, it is exemplary of the way in which empirical analysis can develop concepts and observations which should inform theory. One of the most interesting arguments in 
this respect is the account of the emergence of a conception of public property which derived from the aesthetic and nationalist discourses of the Thirlmere Defence Association (pp.79-86). Such claims were not new, as Thomas Lekan has demonstrated in his Imagining the Nation in Nature, German preservationists had earlier in the century made similar claims that there were forms of landscape which, because of their role in the imagination of the national past, acquired a form of status beyond that of mere private property to be alienated at will. Ritvo places this development of this phenomenon in Britain firmly in the late-nineteenth century, indicating that it was a somewhat later development in this context, perhaps because of the very strength of countervailing modernizing tendencies which in the end rather easily won the battle over Thirlmere. Nonetheless it is apparent that imagining a particular landscape as a form of national property enables political arguments for preservation that are not necessarily possible in other contexts, albeit arguments that as Ritvo suggests here were strongly inflect by class and political ideology. One wonders what Manchester's Radicals made of the whole Thirlmere project, the sight of landowners defending their property rights must surely have provoked ire. Indeed, the problem of environmental resources as property abounds in this look. From the buying-out and compensation of landowners to the Manchester Corporation's claim over the lake as property of an urban population the problem of the competing property claims is omnipresent. One of the important observations of The Dawn of Green is about the slippery nature of property as a cultural phenomenon and the consequences of this for environmental politics. This is surely worthy of further investigation.

The emergence of environmental history as a core part of research and teaching within world history is one of the most encouraging and exciting trends at present. Burke and Pomeranz's collection The Environment and World History brings together many of the outstanding scholars of global environmental history and provides a volume that is both broad in geographical and temporal scope as well as exciting in terms of interpretive ambition. There can be little doubt but that this volume will form an essential introduction for undergraduates and graduates studying world history.

The volume seeks to increase the level of methodological and theoretical engagement among environmental and world historians, and is driven by the interpretive concerns of the New World History. The Environment and World History seeks to extend the study of environmental history beyond what its editors see as the confining narrative of the consequences of industrial modernity. It challenges narratives that would make the rise of industrial capitalism central to the experience global environmental change, and seeks to extend the story of the making of environmental modernity beyond the confines of Europe. The adequacy of world-systems approaches to environmental history is implicitly under challenge in The Environment and World History. In place of which the editors suggest three themes. The first is the important of relations between state formation and environmental change; the second the study of 'deep histories' of human-environmental interaction, and the third is the importance of regional peculiarity. The most significant single concept binding together this collection is, however, the idea proposed by the authors of 'developmentalism'. Developmentalism acts as the organising concept for the volume, which helps to structure contributions which range widely from the history of the Rhine to Latin American environmental history. Because of the theoretical centrality which this 
concept plays in giving coherence to this collection it requires treatment in some detail.

Developmentalism is intended to challenge accounts of environmental change based on notions of European exceptionalism. There are certain processes, such as the intensification of land use, which the authors claim cannot be explained by looking at European capitalism. Capitalism along with western science, they treat as 'culturally specific variants of patterns found more broadly'. These patterns are the drive from territorial states to 'transform the physical environment for the sake of state power'. The attempt by states globally to increase their power, build state bureaucracies, exploit resources are termed the 'developmentalist project' (p.7). Capitalism may remain crucial to the European story, but this should not obscure countervailing tendencies among non-European states to pursuer development and environmental transformation. Indeed, most environmental transformation the authors argue has historically been carried out by states that were non-capitalist.

In its recognition of the role of states in environmental change and the temporal specificity of the role of capitalism in environmental change, developmentalism certainly contains important analytical insights but as a theory of general environmental change in history it is problematic. From the perspective of Marxist environmental history the idea that all states pursue a drive towards the appropriation of resources for the augmentation of state power need not seem particularly controversial. It is clear that states do have crucial roles, including in non-capitalist contexts, in determining property regimes and the parameters of resource exploitation. The problem with developmentalism, despite the authors' counter-claims, is that it homogenises this process. If developmentalism is characteristic of all states then the concept does little more than to describe the universal (rather than historically particular) character of state-nature relations. Rather than providing a global history, this would suggest that environmental history must necessarily be conducted at the level of the state, and in practice this is how the authors in the collection proceed. Moreover, this state and resources centred analysis makes much more difficult the study of the political-ecological effects of environmental transformation. Where are the resistances and points of blockage in this story of 'developmentalism', where are the Thirlmeres?

In this regard it is rewarding to read The Environment and World History alongside Rethinking Environmental History as these two volumes of essays, while taking different theoretical paths, reinforce and critique one another. Rethinking Environmental History certainly demonstrates the possibilities of thinking with a combination of world-systems and Marxist theory. The essays collected by Hornborg, McNeill and Martinez-Alier seek on the one hand to uncover the ways in which social processes become embodied in nature and, on the other, they unravel the impact of uneven development and unequal exchange on global questions of environmental justice. There is none of the homogenising effect of the concept of 'developmentalism' here. Rather, there is an empirically and theoretically rich account of the exchanges of energy and matter through a global economic system driven by the priorities of capital accumulation (this is a volume primarily, though not exclusively, about capitalisms evolving relations to nature). The influence of 'ecological economics' is apparent here, and it is the account of the global evolution 
of a social metabolism which most stands out, to some extend answering the problems of periodization raised by The Environment and World History.

One of the most compelling chapters in this collection, among many excellent contributions, is that by J.W. Moore on 'Silver, ecology and the origins of the modern world, 1450-1640' (pp.123-142). Moore first brilliantly outlines the flaws in accounts of global environmental history which fail to recognise the revolutionary break constituted by the emergence of capitalism in Europe and the consequences that followed from an 'endless accumulation [that] embodied a globalizing mode of producing nature that presumed the endless export of ecological problems' (p.123). Rather than an emphasis on the limits of developmentalist states, only uniquely overcome in Europe because of the contingent availability of cheap energy, Moore emphasising the tendency of capitalism to continually overcome limits by exporting them to new sites. This approach emphasises not natural limits so much as the malleability of nature and the capacity capital has exhibited to produce and reproduce natural conditions that enable accumulation even where they may undermine social needs. Moore demonstrates precisely the ways in which the monetization of the European economy drove the transcendence of ecological 'limits' and the expansion into and incorporation of external ecologies into the value producing mechanisms of capital. At the moment of its birth, then, capitalism was linked to a global process which demanded the production and transformation of natural relations on a global scale. The global capitalist appropriation of nature was not therefore a phenomenon driven by post-industrial European expansion, but present in the very origins of capitalism as a part of the accumulation process. Moore's essay in this collection therefore throws into sharp relief the unique character of capitalism's relations to nature and raises key questions for environmental history. It is well worth reading this alongside the essays in this collection by J. Donald Hughes, Robert B. Marx and Mats Widgren, which highlight some of the pre-capitalist transformations of social relations with nature in ways that problematise Pomeranz and Burke's developmentalist model.

Moore's approach to 'ecological politics' is particularly incisive, and throws lights on the discussion on unequal ecological exchanges and environmental justice in the second part of this volume. For Moore the politics emerge precisely from the tensions accompanying primitive accumulation in Europe which drove the search for external sources of silver. Ecological politics thus not only reflects disputes over resource allocation or property rights, but influence the various forms that capital's relations with nature take. The outcome of all these processes is a process of continuous attempts to displace ecological contradictions and their social consequences. As Moore puts it the fictitious 'commodification of labor and land undermined the socioecological bases for regional accumulation regimes, setting the stage in these instances not just for the eventual resurgence of the "self-protecting society" but also for a new round of global expansion.

Returning to this review's original problem, the question of which theoretical approaches the environmental historian might possible engage in her work, I would suggest that Rethinking Environmental History offers the richest engagement with theory. It is not without limits or problems, and the question of scale and of whether the local, national, regional or global level of study is the most appropriate for environmental history is a vexed one. This issue is intriguingly problematized by Josiah Heyman's study of the border and the territorialisation of environmental 
politics in Rethinking. However, the question of 'How and with what purpose we write environmental history' seems, at least to this reviewer, to demand more than an empiricist response. There is also clearly a question about the relationship between historical knowledge of past environments and landscapes and their transformation and the present relationship between our own social formation and its relation to nature. From this perspective, I would argue that it is something like the innovative integration of world-systems and Marxist theory that is made in Rethinking Environmental History which offers a way of comprehending the social and political processes that constantly produce and revolutionise our social relations with nature. This also points to the potentially productive connections that can be made between environmental history and the work of Marxist geographers like David Harvey, Neil Smith and Noel Castree on such concepts such as the 'production of nature' and 'social natures'. Of course, this does not exhaust the range of possible theoretical directions for environmental historians to take, but in terms of the requirements of the present moment, it is this iteration of Marxist theory that appears to offer the means for historians to contribute not just to making environmental policy, but to the making of an effective environmental politics. A politics capable of producing the kinds of revolutionary transformation that are a necessary if struggles for global environmental and social justice are to bear fruit.

\section{Timothy Cooper}

University of Exeter (Cornwall Campus), UK 